\title{
Turistik Mekânda Gerçekliğin Algısal Değişimi: Modern ve Post-Modern Turizm Deneyimlerinde Özgünlük
}

\author{
The Perceptual Change of Reality in Tourist Places: Authenticity \\ in Modern and Post-Modern Tourism Experiences
}

\section{Müzeyyen Sağıroğlu}

Amasya Üniversitesi Mimarlık Fakültesi, Şehir ve Bölge Planlama Bölümü, Amasya

\section{ÖZ}

Bir topluma ait kültürel kimliğin ve mekâna ait kültürel birikimin devamlılı̆ı, onları zamanın ve çeşitli dışsal faktörlerin yıkıcı etkisinden korumakla ve özgün karakterleri ile gelecek kuşaklara ulaşmasını sağlamakla mümkün olmaktadır. 1980'lerden itibaren çeşitli politikalar ile tarih ve kültürün küresel piyasaya yeniden sunumu, 1960'larda başlayan özgünlük tartışmalarını turizm bağlamında daha da kuvvetlendirmiştir. Bu derleme çalışması, özellikle 1930lu yıllardan itibaren şekillenen özgünlük kavramının değişen ve evrilen rollerini ortaya çıkararak, modern ve post-modern dönemde turizm deneyimlerinde özgünlük konusunda yapılan başlıca çalışmaları irdelemeyi amaçlamaktadır. Bu bağlamda, makalenin birinci bölümünde, çeşitli uluslararası koruma metinlerinde özgünlük kavramının gelişimi; makalenin ikinci bölümünde, modern dönem turizm yazınında yapılan özgünlük çalışmalarının teorik başlangıcı sayılan Boorstin (I96I) ve MacCannell'ın (I976) ve ardından Cohen'in (1979) çalışmaları; makalenin üçüncü bölümünde ise post-modern dönem turizm yazınında yapılan önemli çalışmalardan olan Urry (1990) ve Wang (1999)'in çalışmaları incelenmiştir. Değerlendirme bölümünde, yapılan araştırmaya dayaI olarak, elde edilen bilgiler özetlenmiş, temel saptamalar sonuç bölümünde tartışılmıştır. Bu çalışma turizm sosyolojisine dayanan eleştirel bir yaklaşımı referans alarak, özgün değerlere sahip kentsel alanın, sahte gerçeklikler ile turist bakışına nesne üreten ve piyasa ekonomisi tarafından yapılandırılmış bir turistik boşluk haline dönüşümü konusunda farklı bakış açılarının geliştirilmesini hedeflemektedir.

Anahtar sözcükler: Özgünlük; sahnelenmiş gerçeklik; sahte olaylar; turizm; turist bakışı.

\section{ABSTRACT}

The sustainability of cultural identity of society and cultural accumulation of space is possible by protecting them from the destructive effects of time and various external factors and by ensuring that they reach to the future with their authentic characters. Since the 1980s, the representation of past and culture to the global market with various policies has further strengthened the debate on authenticity that started in the 1960s in the context of tourism. The aim of the present study was to scrutinize the main works on authenticity in tourism experiences in the modern and post-modern periods by revealing the changing and evolving roles of the concepts of authenticity that has been shaped since the 1930s. In this context, the first part of the present study shows the development of the authenticity concept in international doctrinal documents on conservation. The second part discusses the works by Boorstin (196I), MacCannell (1976), and Cohen (1979), who are considered the theoretical beginning of the authenticity studies in the modern tourism literature. The third part examines the studies by Urry (1990, 1995) and Wang (1999), which are important studies in the post-modern tourism literature. The obtained information based on the research is summarized in the review section. The main implications are discussed in the conclusion part. The present study, which takes a critical approach based on tourism sociology, aims to develop different perspectives on the transformation of authentic urban place into a touristic space structured by the market economy that produces objects for the tourist gaze with constructed false realities.

Keywords: Authenticity; pseudo-events; staged authenticity; tourism; tourist gaze. 


\section{Giriş}

Her medeniyet kurulduğu bölgeye kendi izini bırakmış ve oraya kendi kültürünü yansıtmıştır. Geçmiş günler ile bugünün bağlantısı ve ayrıca bugün ile gelecek günlerin bağlantısı ancak korunması gerekli olan kültürel miras değerleri ile mümkün olmaktadır. Bir kenti diğerinden ayıran benzersiz özellikler, hızla küreselleşen ve aynılaşan dünyada, kentlerin özgün kimliğini oluşturmaktadır. Kültürlerin somut ve soyut unsurları arasında, doğal çevre, kültürel ve tarihi miras ve ayrıca kültürün sembolik öğeleri, dili, dini, gelenekleri ve yemekleri şehirlerin özgünlüğünü ve kimliğini tanımlayan temel unsurlardır. Geleneksel mimari detaylara sahip eski bir ev, bir dini yapı veya tarihi bir kalıntı düşünüldüğünde, sahip oldukları tarihsel geçmiş, önem, estetik ve mimari değer bu miras değerlerinin özgünlüğünü yansıtan ve onları diğer yapılardan ayıran önemli elemanlardır. Özellikle 20. Yüzyılın ortalarından itibaren teknolojik gelişmelerin ulaşım sektöründe yarattı̆̆ı imkânlar aşııması kolay olmayan birçok coğrafi eşiği kolaylıkla aşmayı olanaklı hale getirmiş, el değmemiş doğal ve kültürel alanlara ulaşım olanağı sağlamıştır. Yerel çekicilikleri ile turizm sektörü pastasından pay almaya çalışan alanlardaki doğal ve tarihi çevre koruma ve turizm faaliyetleri eş zamanlı olarak artmış, önceki medeniyetlerin geride bıraktığı iyi korunmuş yapıların birikimi, alandaki turizm faaliyetlerinde canlanmayı ve ziyaretçi sayısında artışı da beraberinde getirmiştir.

Bugün, bacasız endüstri tabiri ile olumlu yönleriyle ele alınan turizm sektörü, yarattığı ekonomik, çevresel ve sosyal etkiler düşünüldüğünde, bu tabirin hakkını verememektedir. Turizm sektörü, olumlu yanlarının yanında olumsuz yanlarıyla da turizm alanlarını çeşitli açılardan etkilemektedir. Özellikle tarihi şehirlerdeki bu 'kısa, ancak oldukça etkili boş zaman etkinliği', kültür, yerel halk, kültürel miras ve özgünlük bağlamında ele alındığında üzerinde düşünülmeye değer bir konudur. Fainstein ve Judd'a göre, tarihi-turistik şehirlere (tourist-historic city) bakıldığında, bu şehirlerin tatil şehirlerinden (resort city) ve dönüştürülmüş şehirlerden (converted city) farklı olarak yapay turistik çekicilikler yaratmasına gerek yoktur, çünkü bu alanlar tarih ve kültür mirasına sahip olan benzersiz alanlardir (1999: 63). Ancak, İngiltere'de özellikle 1980 öncesinde başlayan ve 1980 sonrasında da etkisi artarak devam eden kültür odaklı politikalar ile, bu tarihlerde hızla sanayisizleşen Sheffield, Liverpool ve Glasgow'da olduğu gibi tarih ve kültür piyasaya yeniden sunulmuş ve kentlerin gerileyen ekonomik durumlarına bir çözüm aranmışır (Urry, 1995: 154). Akkar Ercan, kentlerde uzun bir süredir ihmal edilmiş olan kamusal mekânların iyileştirilmesinin ve bu mekânların çok yönlü rollerini etkin bir biçimde yerine getirebilmesinin olumlu bir yön olduğunu belirtse de, küresel-kent olabilme ve bu pazardan pay alabilme adına kentlerin merkezlerinde ve tarihi ve kültürel mirasın yoğunlaştığı alanlarda özellikle 1980ler sonrasındaki neoliberal projeler aracılığı ile yeni mekânların üre- tildiğini söylemektedir (2016: 196). İngiltere'de yaptığı 'miras endüstrisi' çalışması ile bu konuda dikkatleri üzerine çeken Hewison (1987) dışında pek çok yazar, miras alanlarının metalaştırılarak bir tema parkı haline getirilmesini eleştirmektedir (bkz Walsh, 1992; Kirschenblatt-Gimblett, 1998). Bir yere ait olan ve oranın özgün kimliğini oluşturan 'tarih ve kültürün yeniden sunumu (kültür endüstrisi)' (Urry, 1995: 154), bu alanlardaki özgünlük tartışmalarını da beraberinde getirmektedir. Bu bağlamda, öncelikle özgünlük kavramının tanımı yapılacak ve çeşitli uluslararası metinlerde bu kavramın tarihsel gelişimi incelenecektir. Post-modern turizmin etkileri 1970ler itibari ile ortaya çıksa da, bu çalışmada 1980'e kadar olan dönem, modern turizmin etkilerinin görüldüğü ve bu döneme ait kuramlar içerdiği için (Uriely, 1997: 984), modern turizm paradigması çerçevesinde, 1980 sonrası ise post-modern turizm paradigması çerçevesinde ele alınmıştır. Derleme çalışmasının ikinci bölümünde, modern dönemde turizmde özgünlük çalışmalarının teorik başlangııı sayılabilecek Boorstin'in (196I), sonrasında MacCannell'ın (1976) ve ardından çalışmasını Boorstin ve MacCannell'ın bu iki teorisi üzerine temellendiren Cohen'in (1979) çalışmaları ele alınacaktır. Üçüncü bölümde, post-modern turizm döneminde yapılmış önemli özgünlük çaış̧malarına odaklanılarak, bu kapsamda Urry (1990) ve Wang (1999) çalışmaları modern döneme de referans vererek açıklanacaktır. Son olarak, genel bir değerlendirme yapılacak ve temel saptamalar sonuç bölümünde tartışılacaktır.

Bu derleme çalışması, eleştirel bir yaklaşımı referans alarak günümüzde teknolojik ve ekonomik gelişmelerle etkisi artarak büyüyen turizm sektörünün ideolojik olarak şekillendirdiği kentsel mekânda, belirgin bir şekilde görülmeyen, görülmediği için algılanamayan aktörler arasındaki çeşitli ilişkileri sorgulamayı ve bu alanda sürdürülebilirlik ve yönetim bağlamında değişim çağrısı yapma amacını taşıyanlar için teorik bir öz ortaya koymayı hedeflemektedir. Bu konuda yapılmış olan çalışmaları incelemek, günümüzde tarihi bir çevre olsun ya da olmasın, turizm alanlarında çok yönlü bakış açılarının geliştirilmesi adına büyük önem taşımaktadır.

\section{Uluslararası Koruma Metinlerinde Özgünlük Kavramının Gelişimi}

Bu bölümde, özgünlük kavramının kendi içindeki müphemlik tartışmalarına değinilmeden özet bir tanımı yapılarak, kavramın uluslararası metinlerde yer alıs şekli açıklanmıştır. Özgünlük kavramı, tanımlanması oldukça zor olan terimler arasında yer almakla birlikte temelde 'orijinal, gerçek ve aslına uygun özelliklerini kaybetmemiş' olarak tanımlanmaktadır. Carta Del Restauro olarak da bilinen Atina Kartasisında (193I), restorasyon projelerinde yapılan hataların yapılarda karakter ve tarihi değer kaybına sebep olacağı belirtilmiştir. Bu ifadede 'özgünlük' kelime olarak metinde yer almasa da bu kavrama dair sınırlı bir anlam çıkarılmaktadır. Özgün (authentic) ve öz- 
Tablo I. Çeşitli uluslararası metinlerle belirlenmiş olan özgünlük ölçütlerinin gelişim aşamaları

\begin{tabular}{|c|c|c|c|c|}
\hline & $\begin{array}{c}1977 \\
\text { DKMKDS } \\
\text { Uygulama Rehberi }\end{array}$ & $\begin{array}{c}1994 \\
\text { Nara Özgünlük } \\
\text { Belgesi }\end{array}$ & $\begin{array}{c}2005 \\
\text { DKMKDS } \\
\text { Uygulama Rehberi }\end{array}$ & $\begin{array}{c}2012 \\
\text { DKMKDS } \\
\text { Uygulama Rehberi }\end{array}$ \\
\hline \multirow[t]{8}{*}{ Özgünlük ölçütleri } & Tasarım & Tasarım ve biçim & Tasarım ve biçim & 2005 \\
\hline & Malzemeler & Malzemeler ve nesne & Malzemeler ve nesne & Dünya Kültürel \\
\hline & İşçilik & Gelenek ve teknikler & $\begin{array}{c}\text { Gelenek/ Teknikler } \\
\text { /Yönetim Sistemleri }\end{array}$ & $\begin{array}{l}\text { Mirasının Korunmasına Dair } \\
\text { Sözleşme Uygulama Rehberi'nde }\end{array}$ \\
\hline & Konum & Konum ve yerleşim & Konum ve yerleşim & \multirow{4}{*}{$\begin{array}{c}\text { Sözleşme Uygulama Rehberi’nde } \\
\text { belirlenen özgünlük ölçütleri } \\
\text { değişiklik yapılmadan } \\
\text { kabul edilmiştir. }\end{array}$} \\
\hline & & Kullanım ve işlev & Kullanım ve işlev & \\
\hline & & Ruh ve anlatım & Ruh ve anlatım & \\
\hline & & $\begin{array}{l}\text { Illk tasarım ve } \\
\text { tarihsel evrim }\end{array}$ & $\begin{array}{l}\text { İlk tasarım ve } \\
\text { tarihsel evrim }\end{array}$ & \\
\hline & & & $\begin{array}{c}\text { Dil ve soyut mirasın } \\
\text { diğer biçimleri }\end{array}$ & \\
\hline
\end{tabular}

DKMKDS: Dünya Kültürel Mirasının Korunmasına Dair Sözleşme. Kaynak: Yazar tarafından oluşturulmuştur.

günlük (authenticity) sözcüklerinin ilk olarak kullanıldığı metin Venedik Tüzüğü (1964)'dür. Eski eserlerin ortak bir miras olarak gelecek kuşaklara orijinal zenginliklerine zarar vermeden taşınması bir görev olarak tanımlanmış, tüzüğün giriş metninde 'authenticity' ifadesinin yerine Türkçe karşılığı olarak 'orijinallik' kelimesi, 'authentic' ifadesinin yerine ise 'orijinal' kelimesi kullanılmıştır.

1972 yılında UNESCO tarafından hazırlanan Dünya Kültür ve Doğa Mirasının Korunması Sözleşmesi'nde 'özgünlük' ifadesine yer verilmemiştir. Bu kavram ikinci olarak, 1977 tarihli Dünya Kültürel ve Doğal Mirasının Korunmasına Dair Sözleşme Uygulama Rehberi'nde, bir yerin Dünya Miras Alanı seçilmesi için gerekli olan ölçütlerden biri olarak yer almıştır. Bir miras değerinin özgünlüğü, 'yapının bulunduğu konumu, tasarımı, malzemesi ve işçiliği' bakımından dört farklı boyutta incelenmiş, zaman içerisinde ortaya çıkan nitelikli değişikliklerin ve sanat ya da tarihi değer taşıyan çeşitli dönemlerdeki eklemelerin önemine de vurgu yapılmıştır (UNESCO, 1977). Bir diğer önemli metin, Washington Tüzüğü olarak bilinen 1987 tarihli 'Tarihi Kentlerin ve Kentsel Alanların Korunması Tüzügüu'dür. Bu önemli metinde, tarihi kentlerin ve kentsel alanların tehdit altında olduğu, ihmal edildiği, harap edildiği ve hatta yok edildiği, bu durumun kültürel, sosyal ve ekonomik kayıplara neden olacağı belirtilmiştir. Kentin veya kentsel alanın tarihi karakteri ve bu karakteri oluşturan maddi ve tinsel bileşenlerin korunması gerektiği vurgulanarak, bu özellikleri tehdit eden olumsuz etkenlerin tarihi kent veya kentsel alanın özgünlüğünü zedeleyebileceği ifade edilmiştir. Bu durumun önüne geçmek adına ilkeler ve hedefler belirlenmiş, çeşitli yöntem ve araçlarla desteklenmiştir (ICOMOS, 1987).

1977 tarihli Uygulama Rehberi'nden 1994 tarihli Nara Öz- günlük Belgesi'ne kadar geçen on yedi sene boyunca, özgünlük kavramının tanımı aynı kalmıştır (Cameron, 2008: 2I). Japonya'da düzenlenen Nara Konferansı'nın sonuç belgesi olan Nara Özgünlük Belgesi'nde ise, daha önce belirlenmiş olan dört farklı özgünlük boyutuna 'kullanım ve işlev, ruh ve anlatım, ilk tasarım ve tarihsel evrim' gibi bazı somut ve soyut boyutlar da eklenerek kapsamı genişletilmiştir (ICOMOS, 1994). 1996 yılında Teksas'ta düzenlenen San Antonio Bildirgesi, özgünlük kavramının, kimlik, tarih, malzemeler, sosyal değer, yönetim ve ekonomi ile olan bağlantısının açıklandığı önemli bir bölgesel metindir. San Antonio Bildirgesi'nde, özgünlük kanıtlarının tespiti için beş gösterge belirlenmiştir: gerçek değerin yansıtılması, bütünlük, kullanım ve işlev, kimlik, bağlam (ICOMOS, 1996). 2005 tarihli Dünya Kültürel Mirasının Korunmasına Dair Sözleşme Uygulama Rehberi'nde ise 'yönetim sistemleri, dil ve soyut mirasın diğer formları' da listeye eklenerek ve 2012 tarihli Uygulama Rehberi'nde aynen kabul edilerek (UNESCO, 2005; UNESCO, 20I2) özgünlük ölçütleri son halini almıştır (Tablo I).

Son olarak, Nara Özgünlük Belgesi'nin 20. yıldönümü 2014 yılında ICOMOS Genel Kurulu'nda kutlanarak, geçen yirmi yıl boyunca bu belge ile neler elde edildiği ve belgenin nasıl uygulandığı tartışılarak Nara Özgünlük Belgesi'nin etkinliği test edilmiştir. 'Nara +20: Miras Uygulamaları, Kültürel Değerler ve Özgünlük Kavramı Üzerine’ adını taşıyan bu belgede, kültürel mirasın korunmasında nesiller arası sorumluğunun, toplum katılımının ve sürdürülebilirlik uygulamalarının önemi tekrarlanarak, kültürel mirasın korunmasında karşılaşılan küreselleşme, kentleşme, demografik değişimler ve yeni teknolojilerin kullanımı gibi zorluklara dikkat çekilmiştir. Tablo 2'de, bahsedilen uluslararası metinler özgünlük bağlamında incelenmiş ve sunulmuştur. 
Tablo 2. Uluslararası metinlerde ‘özgünlük' kavramının kapsamının gelişim aşamaları ve bu metinlerin 'özgünlük' bağlamında önemi

\begin{tabular}{|c|c|c|c|c|}
\hline Uluslararası metinler & Tarih & Organ & Düzenlendiği yer & 'Özgünlük' bağlamında önemi \\
\hline $\begin{array}{l}\text { Carta Del Restauro } \\
\text { (Atina Kartası) }\end{array}$ & 1931 & $\begin{array}{l}\text { Eski Eserler ve } \\
\text { Güzel Sanatlar } \\
\text { Yüksek Kurulu }\end{array}$ & Atina/Yunanistan & $\begin{array}{l}\text { Restorasyon projelerinde yapılan hataların yapılarda } \\
\text { 'karakter ve tarihi değer kaybına' yol açacağı } \\
\text { belirtilmiştir. }\end{array}$ \\
\hline Venedik Tüzüğü & 1964 & ICOMOS & Venedik/Italya & $\begin{array}{l}\text { Eski eserlerin ortak bir miras olarak gelecek kuşaklara } \\
\text { ilk kez 'orijinal' zenginliklerine zarar vermeden taşımak } \\
\text { bir görev olarak tanımlanmıştır. }\end{array}$ \\
\hline $\begin{array}{l}\text { DKMKDS Uygulama } \\
\text { Rehberi }\end{array}$ & 1977 & UNESCO & Paris/Fransa & $\begin{array}{l}\text { Bir miras değerinin özgünlüğü, “yapının bulunduğu } \\
\text { konumu, tasarımı, malzemesi ve işçiliği” bakımından } \\
\text { dört farklı ölçütte incelenmiştir. }\end{array}$ \\
\hline Washington Tüzüğü & 1987 & ICOMOS & Washington/ABD & $\begin{array}{l}\text { 'Kentin veya kentsel alanın tarihi karakterini oluşturan } \\
\text { maddi ve tinsel bileşenleri’ tehdit eden etkenlerin bu } \\
\text { alanların özgünlüğüne zarar verebileceği belirtilmiştir. }\end{array}$ \\
\hline Nara Özgünlük Belgesi & 1994 & ICOMOS & Nara/Japonya & $\begin{array}{l}\text { Dört farklı özgünlük ölçütüne 'kullanım ve işlev, ruh } \\
\text { ve anlatım, ilk tasarım ve tarihsel evrim' gibi bazı somut } \\
\text { ve soyut boyutlar da eklenerek kapsamı genişletilmiştir }\end{array}$ \\
\hline San Antonio Bildirgesi & 1996 & ICOMOS & Teksas/ABD & $\begin{array}{l}\text { Özgünlük kavramının, ‘kimlik, tarih, malzemeler, } \\
\text { sosyal değer, yönetim ve ekonomi’ ile olan bağlantısı } \\
\text { açıklanarak, beş önemli göstergesi belirlenmiştir. }\end{array}$ \\
\hline $\begin{array}{l}\text { DKMKDS Uygulama } \\
\text { Rehberi }\end{array}$ & 2005 & UNESCO & Paris/Fransa & $\begin{array}{l}\text { Yedi farklı özgünlük ölçütüne 'yönetim sistemleri, dil } \\
\text { ve soyut mirasın diğer formları' maddeleri de eklenerek } \\
\text { özgünlük ölçütleri son halini almıştır. }\end{array}$ \\
\hline $\begin{array}{l}\text { DKMKDS Uygulama } \\
\text { Rehberi }\end{array}$ & 2012 & UNESCO & Paris/Fransa & $\begin{array}{l}\text { Özgünlük ölçütleri, Uygulama Rehberleri'nde (1 } 977 \text { ve } \\
\text { 2005) ve Nara Özgünlük Belgesi'nde (1994) belirlendiği } \\
\text { şekliyle kabul edilmiştir. }\end{array}$ \\
\hline Nara +20 Belgesi & 2014 & ICOMOS & Nara/Japonya & $\begin{array}{l}\text { Nara Özgünlük Belgesi (1994) ile geçen yirmi yıl süre } \\
\text { zarfında neler elde edildiği ve belgenin nasıl uygulandığı } \\
\text { sorgulanarak bu belgenin etkinliği test edilmiştir. }\end{array}$ \\
\hline
\end{tabular}

Kaynak: Yazar tarafından oluşturulmuştur.

\section{Modern Dönemde Turizmde Özgünlük Çalışmaları}

Turizm çalışmalarında özgünlük konusunda teorik çatkının 1960'lı yıllar itibari ile şekillenmeye başladığı söylenebilir. Bu konu üzerine yapılan ilk araştırmalardan birini 1961 tarihli 'The Image: A Guide to Pseudo-events in America' adlı kitabı ile Baudrillard'ın (1994) çalısmalarına da kısmen öncülük eden Boorstin yapmıştır. Kitabında, özellikle 20. yüzyılın ortalarından itibaren etkisini oldukça yoğun olarak göstermeye başlayan kitle külttürü, bununla bağlantısı kurarak açıkladığı imge seli (the flood of images) ve gerçek ile sahtenin ayırt edilemediği bir modern toplum eleştirisi üzerine odaklanmıştır. Boorstin'in literatüre kazandırdığı en önemli kavram 'sahte olaylar' kavramıdır. Sahte olaylar, gerçek olayların bir tür sah- te versiyonu olan, tasarlanmış, senaryolanmış ve sahnelenmiş olaylar olarak tanımlanabilir.

Boorstin (196I) From Travel to Tourist:The Lost Art of Travel' başııkı bölümde turist ile gezgini (tourist and traveler) birbirinden ayırarak ikisinin arasındaki farkları ortaya koymuştur. Boorstin'e göre turistler birer keyif düşkünü olarak kendileri için bilinçli olarak hazırlanmış ilgi çekici olayların beklentisi ile turistik yerleri pasif bir rol ile gezerken, gezginler ise aktif olarak insanların, maceranın ve deneyimin gayretli bir arayışı içerisindedir (1961: 85). Benzer şekilde, turizm ve seyahat (tourism and travel) kavramlarını da birbirinden ayırarak seyahati bir sanat olarak değerlendirip, uzak yerlere yapılan zorlu ve çoğu zaman kimsesiz bir macera olduğunu belirtmiş; turizmin ise metalaşmış, pasif ve kalabalık olduğunu, aynı zamanda 
özgün olmadığını belirtmiştir. Seyahat kavramının turizm kavramına dönüşümünü aktif deneyimden, pasif deneyime geçiş olarak adlandırmaktadır (Boorstin, 1961: 85). Modern turizm Boorstin'e (I96I) göre oldukça yüzeysel bir anlam taşır. Kitle turisti ise yerel alandan ve yerel halktan izole olmuş, sahte olayların peşinde koşan, doğal ve kendiliğinden gelişen değil tasarlanarak oluşturulmuş olaylardan, özgün deneyimlerden değil metalaşmış ürün ve kültürlerden zevk alan bir profile sahiptir. Turist balonu (tourist bubble)', dönüştürülmüş şehirlerde gezginleri saran, güvenli ve korunaklı bir alandır (Judd, 1999.) Bir gezginin gerçek riske, tehlikeye ve bir bilinmeyene olan seyahati ile karşılaştırıldığında, modern turistin içinde hiçbir zorluk barındırmayan, güvenli alanlarda gezinmek olarak adlandırılabilen bu risksiz eylemini Richards (200I: 14) 'konforlu bir balon (comfortable bubble)' içinde bulunmak olarak ifade etmektedir. Turizm çalışmalarındaki özgünlük konusunda dikkate değer diğer isim, 1976 tarihli 'The Tourist: A New Theory on Leisure Class' adlı kitabı ile Dean MacCannell'dır. MacCannell'ın (1976: 43) 'bakış (sight)' ve 'bakışın kutsallaştıııma aşamaları (the stages of sight sacralization)' üzerine yaptığı çalışmalar, Urry'nin (1990) 'bakış' (gaze) üzerine yaptığı çalışmalara bir kaynak oluşturmuştur. Çalışmasında modern hayatın sahteliğini (inauthenticity) ve yüzeyselliğini (superficiality) esas alan MacCannell, Boorstin'in ortaya attığı iddiaları eleştirerek, turizmin modern bir kutsal yolculuk olduğunu, turistlerin ise bu yolculukta özgün olan yerleri, kültürleri ve deneyimleri bulmak için uğraş gösterdiklerini söylemiştir. MacCannell'a göre modern toplumdaki yaşam, zamanla değişiklik göstermiştir. Modern zamanda insanlar, hayatın korkutucu yönleri kendileri için çok gerçekçi olmaya başladığında, hayatlarının gerçekliği hakkında kaygı duymaya başlamaktadır (MacCannell, 1976: 93). Modern dünyada insanlar, yaşadıkları şehirden, mahallelerinden, ailelerinden ve hatta kendinin olan her şeyden bağını koparmıştır ve ona yabancılaşmıştır (MacCannell, 1976: 91). Bu yüzden, modern insanlar, kendi hayatlarında bulamadıkları gerçeklik ve özgünlüğün, dünyanın herhangi bir yerinde en saf hali ile bulunduğunu düşünmektedir. 'Diğer insanların gerçek hayatları' ve 'el değmemiş yerler' modern insanlarda merak uyandırmakta ve onları büyülemektedir.

MacCannell temelde, turistleri seyahat etmeye, farklı kültürler ve yerler görmeye iten temel sebebin, turistlerin orada 'gerçek gerçekliğin' bulunduğu hayatları bulma arzusu olduğunu söylemiştir. MacCannell'ın (1976) ortaya attığı bu turist tipolojisi Gray'in (1970) 'wanderlust' olarak adlandırdığı yeni deneyimler, yeni insanlar ve yeni yerler ve kültürler peşinde olan turist tipolojisini hatırlatmaktadır.

Yabancı bir kültürel ortamda, turistler yerel halkın gerçek yaşamlarını onlar gündelik hayatlarını yaşarken görmek isterler. Ayrıca, turistlerin arayış halinde oldukları özgünlük, toplumun gözü önünde yaşanandan ziyade, gözlerden uzak olarak yaşanan ve dışarıdakilere veya yabancılara kapalı olan yerdedir

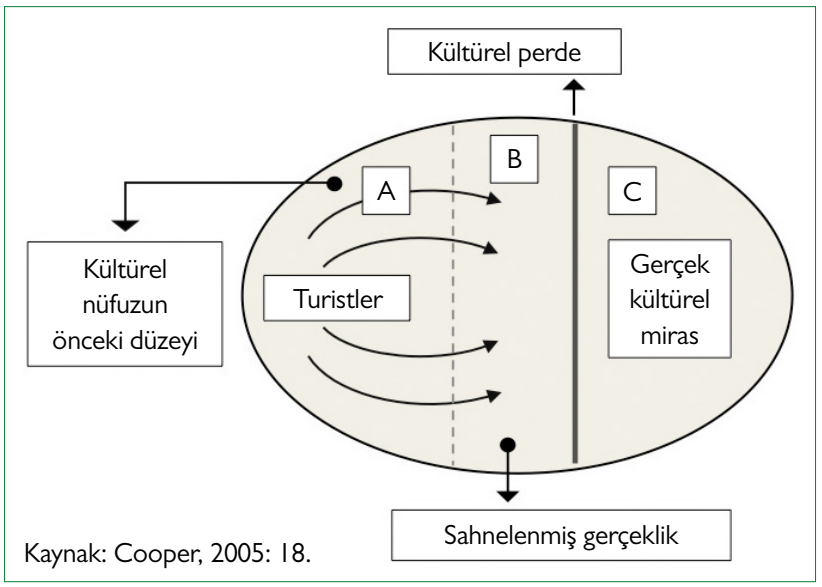

Şekil I. Turistlerin kültürel nüfuz düzeyleri.

(MacCannell, 1976: 93-94). Bu noktada MacCannell'ın çalışmaları büyük ölçüde Goffman'ın (1959) ön ve arka bölge çalışmalarını esas almaktadır. Goffman 'Presentation of Self in Everyday Life' kitabında ön bölgeyi aktörler tarafından performansın sergilendiği (1959: 152), arka bölgeyi ise bastırılmış gerçeklerin gün yüzüne çıktığı yer olarak tanımlamıştır (1959: 69). Ön bölge bir buluşma/görüşme noktasıyken, arka bölge hazırlanma/dinlenme noktasıdır (MacCannell, 1976: 92). Bir başka ifade ile, aktörlerin ön bölgede sergiledikleri performanslar arasında hazırlandıkları ve dinlendikleri yer arka bölgedir. Ön bölgede yalancı gerçeklik (false reality) yaşanırken, gerçek gerçeklik (real reality) arka bölgede yaşanmaktadır. Yine Goffman'a (1959: 90) göre, ön ve arka bölgede oynanan üç farklı rol vardır: performansı sahneleyenler (oyuncular), performansı izleyenler (seyirciler) ve dışarıdakiler olarak adlandırılan, performansta rolü bulunmayanlar. Oyuncular ön ve arka bölgede bulunurken, seyirciler sadece ön bölgede görülür. Performansta rolü bulunmayan ve onu gözlemlemeyen dışarıdakiler ise ne ön ne de arka bölgede bulunurlar.

MacCannell'a göre arka bölgenin izleyicilere ve dışarıdakilere kapalı olması orayı gizemli yapar ve merak uyandırır (1976: 93). Turistlerin bir kısmı, hayatı gerçek (özgün) hali ile görmek istediği için ön bölgeyi aşmanın ve arka bölgede özgünlüğe ulaşmanın çabası içindedir. Bu noktada, turistlerin saklı olan gerçeği görme çabasını bastırmak ve aynı zamanda yerel halkın 'gerçek gerçekliğe' sahip olan arka bölgede bulunan değerlerini korumak için, arka bölge ön bölgede sergilenmeye başlanır. Arka bölgenin özgünlüğüne eriştiğini düşünen turist için aslında olan, arka bölgenin elemanları ile dekore edilmiş ön bölgeden başkası değil$\operatorname{dir}$ (MacCannell, 1976: I0I). MacCannell'ın (1973) ortaya attığı sahnelenmiş gerçeklik (staged authenticity) kavramı ön bölgenin özgün ve gerçek gerçekliğe sahipmiş gibi düzenlenmesidir.

Çalışması MacCannell (1976) ve Goffman'a (1959) dayanan Cooper (2005), turistlerin kültürel nüfuz düzeylerini üç aşamada incelemiştir (Şekil I). Kültürel nüfuzun ilk aşaması olan 
A düzeyi, önceki turistlerin turistik deneyimlerini ifade eder. C düzeyinden bir 'kültürel perde' ile ayrılan B düzeyi, turistler tarafından özgünmüş gibi algılanan ancak 'sahnelenmiş gerçekliğin' olduğu ön bölgedir. Üçüncü aşama olan C düzeyi ise, gerçek kültürel mirasın olduğu, dışarıdakilere ve izleyicilere kapalı olan bölgedir. Kültürel perde izleyicilerin arka bölgeye erişmesini engelleyerek kültürel kimliğin muhafazasını sağlamaktadır (Cooper, 2005: 18). Ancak, yerel girişimciler turistlerin ilgisini daha fazla çekmek ve canlı tutmak adına arka bölgenin elemanları ile ön bölgeyi tasarlar. Yerel halkın da bir parçası olduğu bu durumda, yerel kültür turist talebini karşılamak için kullanılan metalaşmış bir ürüne dönüşmektedir. Turistler arka bölgede gerçekten özgün olana ulaştıklarını zannederken, aslında 'sahte (turistik) bilincin' tehdidi altındadır (MacCannell, 1973: 589).

Turizm çalışmalarında insanları yolculuğa çıkmaya yönlendiren sebepler konusunda turist tipolojilerini araştıran dikkate değer diğer bir isim Eric Cohen'dir. Cohen (1979: 179), Boorstin (196I) ve MacCannell'ı (1976) eleştirerek, argümanlarının turizm çalışmalarında genelgeçer olamayacağını iddia etmiştir. Cohen'in bu konudaki gerekçesi ise farklı karakterlere sahip insanların farklı modda turistik deneyim arzulayabilecek olmasıdır (1979: 180). Boorstin ve MacCannell'dan filizlenen gelenekten farklı olarak, Gray (1970) ve Smith (1977) gibi, Cohen (1972; 1979) de tek tip turist tanımının olamayacağını savunmuştur. Cohen (1979: 183), turistik deneyimler için eklektik olarak din sosyolojisi ve turizm sosyolojisini esas alan beş farklı turist modu önermiştir: eğlence odaklı (recreational) turist modu, dinlenme odaklı (diversionary) turist modu, deneyimsel (experiential) turist modu, deneysel (experimental) turist modu ve varoluşsal (existential) turist modu. Cohen çalışmasında turistleri arayışında oldukları özgünlük derecelerine göre kategorize etmiştir. Turistik deneyimlerin ilk iki modu ile (eğlence odaklı ve dinlenme odaklı iyi zaman geçirme ve gerçeklerden kaçma motivasyonu ile seyahate çıkan kişilere atıfta bulunurken, diğer üç mod (deneyimsel, deneysel ve varoluşsal) ile çeşitli düzeylerde özgünlük arayışı ile motive olan kişileri işaret etmektedir (1979: 183).

Turistik deneyimlerin ilk modu, turistlerin fiziksel ve zihinsel güçlerini yeniden tesis eden, turistlere mutluluk ve esenlik kazandıran ve 'merkeze' yönelik eğlenceli bir yolculuğa dayanan eğlence odaklı (recreational) turist modudur. Cohen (1979: 184) eğlence odaklı turist modunun, Boorstin gibi yüksek kültür taraftarlarının perspektifinden sığ, içi boş bir görüntü sunan, önemsiz ve çoğunlukla manasız bir aktivite olarak görüldüğünü ve alay edildiğini söylemektedir. Eğlence odaklı turistler özgün olmayan ve yapay olarak bilinçli bir şekilde yaratılmış deneyimlere ve yerel kültürün metalaşmış gösterilerine aldanırlar. Cohen (1979: 184) eğlence odaklı turistlerin bu denli kolay aldatılabilir olmasını onların sadece bilgisiz olmalarından değil, aynı zamanda özgünlüğe önem vermemelerinden kaynaklandığını Huetz de Lemps'in (1964) çalışmasına referans vererek açıklamaktadır. Bu noktada, Cohen'in (1979) eğlence odaklı turist modu, Boorstin'in (196I) sahte olaylarla güdülenen turist tipolojisini yansıtmaktadır. Yapay, ancak eğlenceli bir yapıya sahip olan bu turistik gerçekliği korumak için eğlence odaklı turistlerin her biri oyun içerisindeki kendi rollerini bilinçli bir şekilde oynar (Cohen, 1979: 184). Cohen'e göre böyle bir tatil, gündelik hayatın baskısına dayanamayacak hale gelen modern insan için bir basınç supabıdır (1979: 185).

Cohen'in (1979) kategorize ettiği ikinci turistik deneyim modu, turizmin rekreasyonel boyutu önemini yitirdiğinde ortaya çıkan dinlenme odaklı (diversionary) turistik moddur. Cohen, dinlenme odaklı turist modunu 'merkezsiz insanın anlamsız hazzı' olarak tanımlamıştır (1979: 186). Dinlenme odaklı mod da eğlence odaklı mod gibi monotonluktan kaçış esasına dayanır, ancak dinlenme odaklı mod turistlerin eğlenmesine yönelik olmaktan ziyade, fiziksel olarak bedeni iyileştiren ve mental olarak ruhu rahatlatan bir kaçışa yöneliktir (Cohen, 1979: 185). Dinlenme odaklı turistler, hayatları anlamsız olmasına rağmen ne kendi toplumlarında ne de dünyanın herhangi bir yerinde bir anlam bulma arayışı içerisinde değildir. Cohen'e göre eğlence odaklı ve dinlenme odaklı turist modları, 'modern insan ne ölçüde yabancılaşmıştır?' sorusuna verilecek cevap ile de birbirinden ayrılabilir. Bu soruya yanıt vermeden, eğlence odaklı ve dinlenme odaklı turistik modlarından hangisinin daha yaygın ve geçerli olduğunun bilinemeyeceğini vurgular. Buna göre, eğer modern insan batılı değerlerin merkezi bağına sıkıca bağı ise geçerli olan seyahat tarzı eğlence odaklı, modern insan bu değerlerden yabancılaşmış olarak algılanıyorsa geçerli olan seyahat tarzı dinlenme odaklı turistik moddur (Cohen, 1979: 186).

Turistik deneyimlerin üçüncü modu, büyüsü bozulmuş insanların (disenchanted people), kendilerindeki gün geçtikçe artan yabancılaşmanın ve gündelik hayatlarındaki anlamsızlığın farkına vardığında ne olacağına odaklanan deneyimsel (experiential) turist modudur (Cohen, 1979: 186). 'Uyanan' insanlar olarak ifade edilen bu kişiler, toplumlarını devrim yoluyla değiştirmeye ve başkalarının yaşamlarındaki anlamı bulmaya çalışmaktadır. Cohen (1979: 187) deneyimsel turisti, kendi ruhani merkezini ve özgün hayatını kaybeden, 'başka yaşamların gerçekliğini' deneyimleyerek kendi hayatındaki anlamı tekrar oluşturmaya çalışan kişi olarak tanımlamaktadır. Deneyimsel turistin kendi günlük hayatı ile tüm bağlarını koparması, özgün bir toplum yapısının dünyanın herhangi bir yerinde olduğuna dair inancı ve hayatın anlamını yeniden bulma çabası onu MacCannell'ın (1976) turist tipolojisine benzer kılar. Ancak, Cohen deneyimsel turist modunun başka kültürlerde ön bölgeyi aştıklarını ve özgün olana eriştiklerini zannettikleri anda aslında karmaşık bir aldatmacanın (sahnelenmiş gerçekliğin) kurbanı olabileceklerini belirtmektedir (1979: I87). 
Kendi toplumlarının manevi merkezi ile bağlantılarını yitiren, alternatif yaşam tarzları ve din arayışında olan insanları tanımlayan dördüncü mod, deneysel (experimental) turist modudur. Cohen'e (1979: 189) göre mistisizm, narkotik maddeler ve buna benzer diğer şeyler seyahat dışındaki diğer arayış biçimleridir. Deneyimsel turist 'başkalarının gerçek hayatında' sadece bir gözlemci olarak kalırken, deneysel turistler 'başkalarıın gerçek hayatlarına' katılırlar, ancak o yaşamı kabullenmeyi reddederler. Deneme ve yanılma yoluyla farklı alternatifleri deneyen ve karşılaştıran deneysel turistlerin esas olarak aradıkları şey kendileridir (Cohen, 1979: 189).

Cohen'in beşinci ve son olarak belirlediği turistik deneyim modu, seçtiği manevi merkeze tamamen bağlı olan gezginlerin karakteristiklerini tanımlayan varoluşsal (existential) turist modudur. Varoluşsal turistler için, manevi merkezden uzakta olan yaşam sürgünde yaşamak gibidir, çünkü anlamlı gerçek hayat sadece bu merkezdedir. Onlar, manevi merkeze göre oluşmuş kültür ve düzenlenmiş topluma seyahat etmek, kendilerini oraya adamak ve yeni bir hayata başlamak isteyen kişilerdir. Bir bakıma bu kişiler yerli olmaya çalışmaktadır. Cohen (1979: 190) varoluşsal deneyimleri turistik bir olgu haline getiren şeyin, bu turistlerin iki dünya-günlük yaşamlarının dünyası ve seçmeli merkezlerinin dünyası- arasında yaşadıkları hayat olduğunu söylemektedir. Cohen (1979), MacCannell'ın (1976) turizm ve kutsal yolculuk hakkındaki görüşlerini eleştirmiştir. Daha önce bahsedildiği üzere, MacCannell'a (1976) göre hac ve tur aynı güdüye sahiptir, çünkü her ikisinde de turistler özgün deneyimlerin peşinde olan çağdaş bir hacıdır. Cohen'e göre ise varoluşsal turistlerin yolculuğu hac yolculuğuna benzer (1979: 190). Ancak, daha ayrıntılı olarak Cohen (1979), geleneksel hac ve varoluşsal hac arasında farklılıkları ortaya koyarak, geleneksel hac yolculuğunun dinin merkezine yapılan kutsal bir seyahat olduğunu, varoluşsal hac yolculuğunun ise dini bir olgu olmadığını, kaostan başka bir kozmosa, anlamsızlıktan özgün yaşama bir yolculuk olduğunu belirtmiştir (1979: 191). Kısacası, Cohen (1979) çalışmasında genel anlamda yüzeysellikten özgünlüğe doğru giden, zevk arzusundan anlam arayışına evrilen, eğlence odaklı turist modu ile başlayıp varoluşsal turist modu ile sonlanan beş aşamalı bir turistik deneyim tipolojisi oluşturmuştur. İlk iki mod(eğlence odaklı ve dinlenme odaklı turist), Gray'in (1970) rahatlamayı ve dinlenmeyi hedefleyen 'sunlust' olarak tabir ettiği turist tipolojisini, sonraki üç mod (deneyimsel, deneysel, varoluşsal turist) ise, Gray'in (1970) yeni yerler, maceralar, kültürler ve insanlar peşinde olan 'wanderlust' olarak tabir ettiği turist tipolojisini anımsatmaktadır.

\section{Post-Modern Dönemde Turizmde Özgünlük Çalışmaları}

Boorstin ve MacCannell'ın modern dönemdeki kitle turizmini ve modern turisti anlama çabaları, zamanla yerini post- modern döneme ve post-modern turisti anlama çabalarına bırakmıştır. Urry'nin ilk basım tarihi 1990 olan 'Tourist Gaze' kitabı bu konudaki önemli çalışmalardan biridir. Urry (1990) çalışmasında, çeşitli toplumlarda ve özellikle farklı tarihsel dönemlerdeki sosyal sınıflarda turist bakışııın değişimine ve gelişimine odaklanmaktadır.

MacCannell'ın (1976) turizmi bir özgünlük arayışı olarak tanımlamasından farklı olarak, Urry (1990: II) turizm örgütlenmesinin temelinde özgünlük arayışının olduğunu öne sürmenin doğru olmadığııı belirtmiştir. Tamamen inandırıcı bulmasa da, Urry Gottlieb'in (1982) çalışmasına referans vererek insanların tatilden beklentisinin gündelik yaşantılarının aksi bir yaşam olduğunu belirtmiştir. Bunu açıklamak için ise, alt sınıftan gelen turistin bir günlügüne $\mathrm{kral} / \mathrm{kraliçe} \mathrm{olmak} \mathrm{istemesini,} \mathrm{orta}$ sınıftan gelen turistin bir günlüğüne köylü olmak istemesini örnek olarak vermiştir. Urry'ye göre turistler, olağan iş veya ikamet yerleri ile turist bakışının nesnesi arasında fark bulunmasından ötürü, günlük deneyimlerine bir zıtlık söz konusu olduğu için özgün öğeler olarak gördükleri şeylerin peşinden koşarlar. Bu bağlamda, turizm motivasyonunun kaynağı sıradan ve gündelik olan ile sıra dışı arasındaki temel bir ikilemdir (Urry, 1990: II). Urry turistik bakışın temel niteliklerini dokuz madde altında sınıflandırmıştır (1990: 2-3). Buna göre:

- Turizm gibi boş zaman etkinliğinin varlığı onun karşııının varlığına bağıııı, bu da çalışma zamanıdır.

- Turizm bir yerden diğerine hareketi, hedef destinasyonu ve yeni bir yerde konaklamayı içerir.

- Kısa süreli ve geçici olan yeni yerlerdeki konaklama süresi, tekrar eve dönme niyetini içerir.

- Turistler gittikleri yerlerde çalışma ile doğrudan ilişkisi olmayan şeylere bakarlar.

- Modern toplumlarda yaşayan nüfusun önemli bir kısmı turistik faaliyetlere katilır.

- Destinasyonlar, orada bulunan detaylara uzun süre bakılacak şekilde seçilir, çünkü turistlerin oraya ilişkin yoğun haz beklentisi vardır.

- Gündelik yaşamda karşılaşılmayan, olağandışı sahneler içerdikleri için kır ve şehir manzaralarına uzun uzun bakılır.

- Turist bakışı göstergeler aracılığı ile oluşur ve turizm bu göstergelerin birikimidir.

- Turizm profesyonelleri birbirleri ile rekabet halinde turist bakışının yeni nesnelerini yeniden üretme çabasındadır.

Turist bakışının, yerel halkın yaşamına izinsiz, çoğunlukla kabul edilemez ve davetsiz bir girişi içermesi Goffman'ın (1959) çaıışmalarında ön ve arka bölgede oynanan üç farklı rolden biri olan performansı izleyenleri (seyircileri) hatırlatmaktadır. Ayrıca, performansı sahneleyenlerin yani oyuncuların yerel turizm girişimcileri ile sahnelenmiş özgünlük etrafında organize ettikleri yapay sahne gerisini (arka bölgeyi), Urry (1995: 140)turist mekânları olarak adlandırmıştır. Urry (1990: 45) turist bakışını 
ideal tiplere ayırarak tek bir turist bakışının olmadığını belirtmiştir. Farklı toplumsallıkları yansıtan farklı turist bakışlarından burada bahsedilecek olan romantik bakış ve kolektif bakıştır.

Bakılan nesnelerle kurulan kişisel ve yarı-tinsel ilişki üzerine temellenen romantik bakışa sahip turistler nesnelere yalnızken ya da özel ve önemli belli başlı kişiler ile bakmayı tercih ederler (Urry, 1990: 45). Destinasyonun bozulmadan korunmuş doğal yapısı, gözlerden uzak olması, insana ait hiçbir izin olamaması ya da ıssızlığı, kirlenmemiş olması romantik bakışa sahip turistleri güdüleyen faktörlerdir. Başka bir anlatım ile, romantik bakışa sahip turistler, kendilerini etraflarından soyutlayarak, yalnız, tefekkür halinde ve sonsuz bir arayış ile tek başlarına bakabilecekleri yerlerin peşinde olurlar. Ancak, Urry (1995: 19I) romantik bakışın görü ve huşu gerektiren auratik bir bakış olduğunu, bakılan nesnelerdeki özgünlük eksikliğinin, nesnelerin özgünlüğü ve doğallığını önemseyen romantik bakışa sahip turistleri önemli ölçüde etkilediğini belirtmiştir.

Kolektif bakış ise romantik bakışın aksine keyifli bir etkinlik gibidir (Urry, 1990: 45; Urry, 1995: 198). Bir alanda canlılığın, hareketin, kutlamanın, karnaval havasının olması alanda başka insanların da olmasına bağlı olmakta, bir alanda çok sayıda insanın bulunması ise oranın mutlaka gidip görülmesi gereken yer olduğuna işaret etmektedir (Urry, 1990: 46). Seyredilen nesnelerin kolektif görsel tüketimi için kalabalıklar gereklidir. Yalnız bir tefekkürden ziyade, kolektif bakış daha fazla katılımı, pastişi ve kiçi vurgular, bakış tanıdık olana yöneliktir. Özgünlük eksikliği, vurgusu komünal etkinlik ve birliktelik üzerine olan kolektif turistler için kritik değildir (Urry, 1995: 191). Özetlemek gerekirse, kolektif bakış anti-elitist düşünce tarzına dayanan anti-auratik bir özelliğe sahipken, romantik bakış, auratik ve dolayısıyla daha elitist ve yalnızdır. Romantik bakış, turist karşıtı davranışa ve bireyselleştirilmiş turizm biçimlerine gönderme yaparken, toplu bakış turist davranışı ve kitle turizmi anlamına gelmektedir (Smith, 2002: 7). Dahası, romantik bakış kültürel özgünlükle bağlantılıdır, oysa kolektif bakış rekreasyona yöneliktir (Farias, 2008: 20).

Modernizm, Urry (1990: 84) için değişik kültürel alanların yatay ve düşey anlamda yapısal farklılaşmasını ifade ederken, post-modernizm ise anti-hiyerarşiktir ve aynılaşmayı ifade eder. Post-modernizmde kültürel alanın ayırt edici özelliklerinin çöktüğünü ve her birinin diğerinin içine nüfuz ettiğini ve bu yeni kültür biçiminin artık auratik olmadığını ifade etmiştir.. Urry'ye göre (1990: 84),post-modernist kültür anti-auratiktir.

Urry (1990: 100) post-turist kavramını, onu ilk tanımlayan kişi olan Feifer'e (1985) referans vererek açıklamıştır. Bu tanıma göre, post-turistlerin üç temel özelliğinden bahsedebilmek mümkündür. İlki, modern turistlerden farklı olarak postmodern turistler turist bakışının tipik nesnelerini görebilmek için evlerinden ayrılmak zorunda değildir. Dünya üzerinde bulunan herhangi bir nesneye uzun uzadıya bakmak, onları birbirleri ile karşılaştırmak ve sonrasında ne zaman istenirse tekrar bakmak artık multimedya aracılığı ile mümkün olmaktadır. Post-turistler sıklıkla evlerindeyken, yer değişikliğine gerek kalmadan, kendisini gerçekten de oradaymış gibi hayal edebilmektedir (Smith, 2003: 35).

İkincisi, post-turist özgünlügün değil, haz duygusunun peşinden koşmaktadır. Elitist kültürün kısıtlarından kurtulmuş olan, oynanacak oyunların çokluğundan zevk duyan post-turist için dünya bir sahnedir (Urry, 1990: 100). Post-turistler popüler olana ilgi duymakta ve her türlü nesne -ister bir sanat eseri olsun isterse sıradan bir insanın gündelik yaşamına ait bir obje olsun- post-turistler tarafından eşit ölçüde değer bulunmaktadır. Urry post-modern turistin anti-elitist yanını yansıtan bu durumunu 'auradan nostaljiye geçiş' olarak adlandırmaktadır (Urry, 1990: 130). Üçüncü ve en önemli olan özellik ise post-turistler turist olduklarının, özgün bir turist deneyiminin olmadığının, turist deneyiminin anlamsız olduğunun, turizm sektörünün senaryolanmış ve metalaşmış bir oyun olduğunun farkındadır (Urry, 2009: 162; Smith, 2003: 21). Bu özelliği ile Feifer ( 1985: 27I) post-turisti 'kararlı bir gerçekçi' (resolutely realistic people) olarak tanımlamıştır (Urry, 1990: 101).

Wang (1999) 'Rethinking Authenticity in Tourism Experience' isimli makalesinde özgünlügün farklı yerlerdeki farklı insanlar için farklı anlamları olabileceğini belirterek özgünlüğün tek bir tanımının olmadığını belirtmiştir. Wang'ın çalışmaları (1999), nesnelcilik, konstrüktivizm ve post-modernizm ışığında turist deneyimlerindeki özgünlügün anlamının açıklanmasına dayanmaktadır. Wang (1999: 35I) turizmde özgünlük konusunu iki ayrı başlığa ayırarak incelemiştir: özgün deneyimler ve turistik nesnelerdeki özgünlük. Wang bu noktada özgün deneyimleri Handler ve Saxton'ın (1988) çalışmasına referans vererek bireylerin hem gerçek dünya ile hem de gerçek benlikleri ile temas halinde olduklarını hissetmeleri olarak tanımlamıştır. Bir başka ifade ile bireylerin orijinal olan şey hakkındaki bilgisi ile onların gerçek hayatta yaşadıkları deneyimin örtüşmesi özgün deneyimdir. Bu bağlamda Wang (1999), iki başlık altında üç özgünlük türü belirlemiştir.

Wang'in (1999: 352) belirlediği ilk başlık nesneye-bağlı özgünlüktür (Şekil 2). Nesneye-bağlı özgünlük, nesnel özgünlük ve yapısal özgünlük olarak ikiye ayrılır. Nesnel özgünlük, orijinal olanların özgünlügüüü tanımlayan müze bağlantılı bir ifadedir. Ivanovic'e göre (2008: 323) nesnel özgünlügüun bu tanımı Nara Özgünlük Belgesi'ndeki tanımına atıfta bulunmaktadır. Wang ise hem Boorstin'in hem de MacCannell'ın, sahte olaylar ve sahnelenmiş gerçeklik kavramlarını göz önünde bulundurarak, müze bağlantılı ve nesnel özgünlük anlayışında olduklarının üstünde durmaktadır (1999: 353). Özgün deneyimlere yönelik turistik arayışlar, özgün olduğu belirlenmiş turistik nesnelerin (toured objects) epistemolojik deneyiminden başka bir şey değildir. 


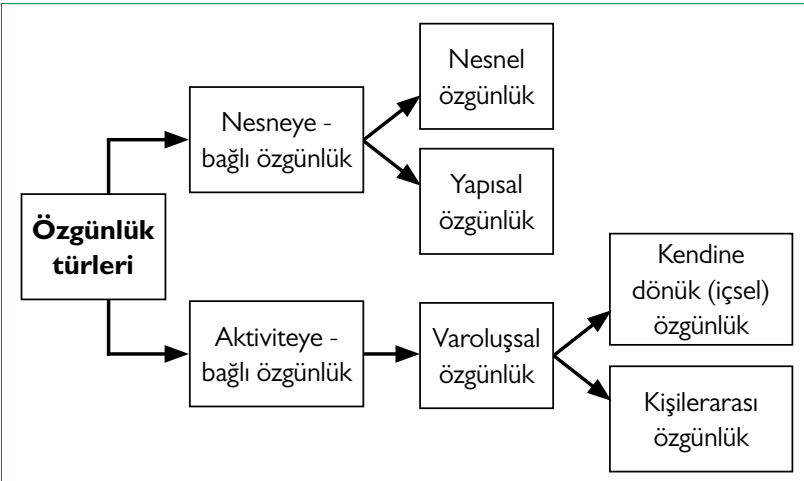

Wang'in (1999) çalışmasına göre yazar tarafından oluşturulmuştur.

Şekil 2. Wang'e göre (1999) özgünlük sınıflandırması.

Wang'e göre (1999: 35I), Boorstin ve MacCannell'ın çalışmalarında olduğu gibi özgünlüğün müze-bağlantılı tanımı turist deneyimlerinde özgünlüğün karmaşık doğasını basite indirgemektedir. Özgünlüğün bu karmaşık yapısının sadece nesnellik bağlamında incelenmesi yetersiz kalmaktadır. Yapısal veya sembolik özgünlüğün temeli ise konstrüktivist yönteme dayanmaktadır. Bu yönteme göre aynı şeyin çeşitli perspektiflerden farklı zamanlardan kaynaklanan ve çoklu ve çoğul anlamları vardır. Yapısal özgünlük turistler tarafından turistik nesnelerin, turistlerin veya turizm girişimcilerinin imgelem, beklenti, algı, inanç ve güç gibi yönler üzerinden tasarlamış oldukları özgünlüğü tanımlamaktadır (Wang, 1999: 352). Turistler özgünlük arayışındadır; ancak, onların arayışı nesnel özgünlük için değil, yapısal özgünlük içindir. Özünde özgün olmayan alanlar turistler tarafından özgün olarak algılanabilir, çünkü bu alanlar zaman içinde kendi kültürlerini oluşturmuştur. Yapısal özgünlüğe göre, turistik nesne farklı perspektiflerden farklı özgün anlamlar taşımaktadır ve özgünlük bu nesne için sembolik bir değerin ifadesidir.

Wang'in (1999: 352) belirlediği ikinci özgünlük başlığı ise aktiviteye-bağlı özgünlüktür. Varoluşsal özgünlük bu başlık altında ele alınmıştır. Varoluşsal özgünlük, turistik aktivitelerle aktif hale gelen özgünlük algısını anlatmaktadır. Turistik nesnelerin özgünlüğünden gelen özgün deneyimlerdeki bu farklılaşma varoluşsal özgünlüğü tanımlamaktadır. Bu yüzden, varoluşsal özgünlüğün turistik nesnelerin özgünlüğü ile bir ilişkisinin olmadığı söylenebilir. Wang (1999: 359) turistik nesnelerin turistler tarafından tamamen özgün olmayan bir şekilde algılanmasına rağmen, onların alternatif bir özgünlük arayışında olmaya devam edeceklerini belirterek bunun varoluşsal özgünlük olduğunu söylemiştir.

Turistik nesnelerin gerçek olup olmadığını sorgulayan nesnel ve yapısal özgünlük dışında, varoluşsal özgün deneyim, turist faaliyetleri tarafından harekete geçirilen duygulardan oluşmaktadır. Bu özgünlük türünde insanlar, kendilerini 'günlük yaşama göre çok daha özgün ve daha özgür olarak ifade ettiklerini' hissetmektedir (Wang, 1999: 35I-352). Varoluşsal özgünlüğe göre, doğası gereği özgün olan hiçbir şey yoktur ve özgün deneyimler sadece insanların aklındadır. Varoluşsal özgünlük, insanlar tarafindan hissedilen bir olgu olup nesnel ve yapısal özgünlük gibi çevrede bulunmaz, ancak algılanır. Otantik yerler için yapılan arayışın aksine, turistler kendi özgün benliklerinin arayışındadır.

\section{Genel Değerlendirme}

Özellikle 20. yüzyılın ikinci yarısından sonra turizm sosyolojisi yazınında öne çıkan özgünlük kavramı, tanımlanması oldukça zor olan ve farklı perspektiflerden bakıldığında farklı anlamlar taşıyan kavramlardan bir tanesidir. Bu çalışmada, 1931 ile 2014 yılları arasında hazırlanan çeşitli uluslararası koruma metinlerinde bu kavramın gelişim süreci incelenmiş, bu bağlamda Dünya Miras Komitesi'nin uygulama rehberlerinde belirlediği özgünlük ölçütlerinin zaman içerisindeki değişimi ortaya konulmuştur. Turizm çalışmalarında özgünlük konusu, 1980 yılı bir kırıma noktası olacak şekilde iki ayrı dönemde incelenmiştir. 20. yüzyılın ikinci yarısı ile 1980'e kadar olan dönemde özgünlük konusu, modern turizm yazını bağlamında, 1980'den sonra olan dönemde ise post-modern turizm yazını bağlamında ele alınmıştır.

Modern dönemde turistik deneyimlerin doğasını anlama üzerine turizm yazınının gelişimi ile birlikte, zamanla turistik mekanların gelişimi ve tüketimine dair farklı teorik bakış açıarı ortaya çıkmışır. Özellikle 20. yüzyııın ikinci yarısından itibaren, Amerikalı tarihçi Daniel Boorstin'in (1961) çalışması, turizmin doğası hakkında yeni tartışmaların başlamasına neden olmuştur. Turistin ve motivasyon kaynağının, turistik çekicilikler ile bağlantısını araştırdığı kitabında, turizmin sahte olayların bir koleksiyonu olduğunu, turistlerin ise sahte deneyimlerin peşinde olduğunu belirtmektedir. Ona göre turistler, yüzeysel ve özgün olmayan deneyimleri tüketerek günlük gerçekliklerden kaçmaya çalışmaktadır. MacCannell (1976) ise modern toplumlarda turizm motivasyonunun kökenini analiz ederek Boorstin'e karşı argüman geliştirmiştir. Kendi hayatlarına yabancılaşmış olan modern insanlar, dünyanın herhangi bir yerinde, gerçek ve özgün olanın el değmemiş hali ile bulunduğunu düşünmektedir. MacCannell'a göre, modern turistlerin motivasyonu, yerel halkı gündelik hayatlarındayken, bir bakıma 'gerçek gerçeklik' durumunda görme isteğidir. MacCannell (1976), ön ve arka bölge kavramı ile, yerel halkın gerçek gerçekliğe sahip olan yaşamlarının arka bölgede saklı olduğuna, turistlerin ise ön bölgede bulunduğuna işaret etmektedir. Turistlerin gerçek gerçekliğe ulaşma isteğinin önüne geçmek ve arka bölgede bulunan özgün değerleri korumak adına, ön bölgenin arka bölgenin sahte elemanları ile dekore edilmesini 'sahnelenmiş gerçeklik' olarak ifade etmiştir. Cohen'in (1979) yaptığı çalışma ise, Boorstin (196I), Gray (1970), MacCannell (1976) ve Smith'in (1977) çalışmalarının eklektik bir ürünü gi- 
bidir. Cohen (1979), tek tip turist modunu reddederek turistlerin özgünlük arayışında, yüzeysellikten anlam arayışına doğru evrilen beş farklı turist tipolojisi geliştirmiştir.

Post-modern dönemdeki turizmde özgünlük çalışmalarında ise Urry (1990), turistlerin seyahat motivasyonlarının temelinde özgünlük arayışının olmadığını, turistlerin günlük deneyimlere zıt olan bir hayalin peşinde olduklarını belirtmektedir. Başka bir deyişle, kısa bir süre için de olsa turistleri harekete geçiren motivasyon, gündelik hayatlarındaki yaşamın aksini yaşama arzusudur. Performansın sergilendiği ön bölgenin, arka bölgenin elemanlarıyla organize edilmesi durumunu açıklayan olgu 'sahnelenmiş gerçeklik' (MacCannell, 1973) iken, bu olgunun yaşandığı alanları Urry (I995: I40), 'turist mekânları' olarak adlandırmıştır. Yerele ait özgün değerlerin görsel olarak tüketildiği ve ‘algısal taşıma kapasitesinin' aşıldığı bu alanlardaki turist bakışının dokuz niteliğini belirlemiştir (Urry, 1990: 2-3; Urry, 1995: I32-133). Turistik bakış biçimlerini beş gruba ayırmıştır: romantik bakış, kolektif bakış, seyirlik bakış, çevresel bakış ve antropolojik bakış (Urry, 1995: 191). Bu çalışmada, romantik bakış ve kolektif bakış üzerinde durulmuştur. Romantik bakışa sahip turistler, bakılan nesnelerle yarı-tinsel ve kişisel ilişkiler kurarak, o nesnelere yalnızken ya da çok önemli kişilerle birlikte bir tefekkür ile bakarlar. Kolektif bakışa sahip turistler ise, tanıdık olana kalabalıkların bir parçası olarak coşkuyla bakarlar. Urry'nin romantik ve kolektif bakış biçimi, Boorstin'in, MacCannell'ın ve Cohen'in kavramsallaştırdığı turist tipolojileri üzerine temellenmiş gibidir. Romantik bakışa sahip turist, MacCannell'ın özgünlük arayışında olan turist tipini ve Cohen'in farklı derecelerde de olsa deneyimsel, deneysel ve varoluşsal turist modlarını hatırlatır. Kolektif bakışa sahip turist ise, Boorstin'in sahte olaylardan haz duyan turist tipini ve Cohen'in dinlenme odaklı ve eğlenme odaklı turist modlarını anımsatır. Kısacası, romantik bakış özgünlükle ve gerçeklikle bağlantılı, auratik bir bakışken, kolektif bakış yüzeyselliğe, yapaylığa ve rekreasyona yönelik anti-auratik bir bakıştır. Urry, post-modernist kültürün de anti-auratik olduğunu belirterek, post-turist kavramını onu ilk tanımlayan kişi olan Feifer'e (1985) referans vererek açıklamaktadır. Post-turistler, multimedya aracılığı ile evlerinden çıkmadan dünyanın herhangi bir yerindeki turist bakışının tipik nesnelerini görebilmektedir. Ayrıca, post-turistler özgünlüğün değil, haz duygusunun peşindedir. Onlara göre bir sahne olan bu dünyada, post-turistler oynanacak oyunların çokluğundan haz almaktadır. Ayrıca, post-turist turizm sektörünün senaryolanmış bir oyun olduğunun farkında olan kararlı bir gerçekçidir. Wang (1999), farklı yerlerde yaşayan insanlar için özgünlüğün farklı anlamları olabileceğini belirtmiştir. Özgün deneyim, bireylerin orijinal olan nesne hakkındaki bilgisi ile gerçek hayatta yaşadıkları deneyim örtüştüğü zaman ortaya çıkar. Wang (1999), nesneye-bağlı ve aktiviteye-bağlı özgünlük olmak üzere iki özgünlük türü belirlemiştir. Wang'e göre Boorstin ve MacCannell'ın çalışmaları özgünlüğün müze-bağlantılı tanımı olan nesneye bağlı özgünlük üzerine kurgulanmıştır. Ancak ona göre, özgünlüğün karmaşık yapısı sadece nesnellik bağlamında incelenemez. Turistler özgünlük arayışındadır; ancak, onların arayışı nesnel özgünlüğü bulmak için değil, konstrüktivizmden beslenen yapısal özgünlüğü bulmak içindir. Nesnel ve yapısal özgünlük her ne kadar çevre ile bağlantılı bir anlam taşısa da, aktiviteye bağlı olan varoluşsal özgünlük algıya ve duyguya dayalı bir anlam taşımaktadır. Varoluşsal özgünlüğe göre, özgün deneyimler sadece insanların aklındadır ve doğası gereği özgün olan hiçbir şey yoktur. Özgünlüğün, modern ve modern sonrası dönemde ele alınış şekilleri, farklılaşan tanımları ve çoklu ve çoğul anlamlara sahip olma durumu çeşitli çalışmalarda incelenmiştir; ancak, bu konuda fikir birliğine varılamayan noktalar halen geçerliliğini korumaktadır.

\section{Sonuç}

Özellikle 20. yüzyılın ortalarından itibaren artan turizm faaliyetleri ve onun ziyaret edilen yerlere olan pozitif veya negatif yönde sosyal, ekonomik, çevresel ve kültürel etkisi, ziyaretçi ve yerel halk etkileşimi, ziyaretçinin özgünlük algısı ve turistik alanın artan ziyaretçi sayısı ile birlikte yaşadığı değişim turizm çalışmalarının temel araştırma konuları arasındadır. Bu çalışmadaki vurgu ise modern ve post-modern dönemdeki yazında, turist motivasyonunun kaynağı, turist tipolojileri, turistik alanlardaki turistik nesnelerin sahteliği, sahnelenmişliği ve gerçekliği, ziyaret edilen alanlardaki turistlerin o mekânı nasıl algıladığı üzerinedir. Bu kapsamda, çalışmada modern dönemdeki yazına şekil veren Boorstin ve MacCannell (1976) ve Cohen'in (1979) çalışmaları, post-modern dönemdeki yazına şekil veren Urry (1990) ve Wang'in (1999) çalışmalarına odaklanılmış, turizm sosyolojisi ve özgünlük konulu literatüre katkı sunmak amaçlanmıştır.

Günümüzde, turistler otantik teknelerde balıkçılık deneyimi yaşarken, balıkçılar süpermarketlerde çalışmaktadır (Paul, 2012: 503), Bir hayal üretim ve tüketim fabrikası olan turizm sektörünün müşterisi olan modern insanların, kentsel alana kitleleşmiş etkisi, post-modern insanların ise bireyselleşmiş etkisi dikkate değer konulardır. Rutinden kaçma arzusunda olan yabancı bakış tahrip edici olabilir. Kitleler halinde kendi modern dünyasına yabancılaşarak çeşitli arayışlar peşinde kendi monotonluğunu kısa süreler dahilinde de olsa terk etme arzusunda olan ve gittiği yerde ise yerele yabancı olan bakışların etkisi ise yıkıcı olabilir. Ayrıca, dünya üzerinde bulunan çeşitli tarihi, doğal ya da kültürel çekiciliğe sahip olan herhangi bir alan bir aktivitenin sahte hac yolculuğuna dönüşmeye başladığında, bu yoğun baskı oranın zamanla ticarileşmesine, özgünlüguünün zedelenmesine, sahte olayların ve sahnelenmiş gerçekliklerin artmasına, anlamca boşalmasına ve bir klişe merkezi haline gelmesine neden olabilir.

Piyasa ekonomisinden kaynaklanan çeşitli sebepler ile yerel halkın da bir çıkar grubu olarak 'sahnede' bulunduğu tarihi 
bir mekânda, toplumsal yaşamı besleyen miras alanlarının anlamca boşaltılması, onları gelecek kuşaklara özgün halleriyle bırakma anlayışına terstir. Çeşitli politikalar ile kültürel miras değerlerinin ekonomik ve simgesel rollerine yapılan vurgu, toplumsal ve kültürel rollerine yapılan vurgudan daha baskın olmaktadır. Eğer koruma eylemi turizm sektörü ile işbirliği içinde, çeşitli sosyal, toplumsal ve tarihi olguları göz ardı ederek tüketim odaklı turist bakışına nesne üretme çabası ise, karşılaşılan olumsuz durumlar karşısında kayıtsızılı halinin olması normaldir. Ancak, tarihi mirasın korunması, yabancı bakışı ekonomik çıkarlar uğruna hoşnut etme eylemi elbette değildir ve olmamalıdır.

Yapılan çalışmada, miras alanları müzeleşen, dokunulmaması veya kesinlikle el sürülmemesi gereken yerler olarak ele alınmamakta, miras alanlarında kurgulanan turizm senaryolarında ve üretilen politikalarda üzerinde düşünülmesi gereken farklı yönleri görünür kılmayı amaçlamaktadır. Çok fazla çıkar grubunun bulunduğu, tarihi miras öğelerine sahip kentsel alanlarda koruma süreci karmaşıktır. Unutulmaması gereken, farklı çıkar gruplarının gündelik hayatlarını sürdürdüğü birçok işlevi barındıran kültürel miras alanlarının planlanmasında, kent plancıları ve politika üreticilerinin en önemli görevi ekonomik bağlamın yanında, o mekânın kültürel, toplumsal ve ilişkisel bağlamını da hesaba katmaları olacaktır. Halen gerçek değerini yansıtabilen, çeşitli dönemsel eklentilere rağmen bütünlüğünü kaybetmemiş ve bağlamından kopartılmamış, yerele özgü kimliği yansıtan ve belirli bir kullanım ve işlev verilerek müzeleştirilmemiş kültürel miras değerleri, ancak bilinçli, etkili ve dengeli bir yönetim planıyla, turizm sektörünün ve yabancı bakışın yıpratıcı etkisine rağmen özgünlüğünü koruyarak ayakta kalabilir ve 'gelecek kuşaklara aynen devretme' vaadi bu şekilde gerçekleştirilebilir.

\section{KAYNAKLAR}

Akkar Ercan, M. (2016). Endüstri-Sonrası Kentlerin Değişen ve Dönüșen Kamusal Mekanları. Planlama, 26(3), 193-203.

Baudrillard, J. (1994). Simulacra and Simulation. Ann Arbor: University of Michigan Press.

Boorstin, D. J. (1961). The Image: A Guide to Pseudo-Events in America. New York: Atheneum.

Cameron, C. (2008). From Warsaw to Mostar: The World Heritage Committee and Authenticity. APT Bulletin, 39(2/3), 19-24.

CIAM. (1931). The Athens Charter for the Restoration of Historic Monuments (Carta del Restauro). Athens: CIAM.

Cohen, E. (1972). Toward a Sociology of International Tourism. Social Research, 39, 31-46.

Cohen, E. (1979). A Phenomenology of Tourist Experiences. Sociology, 13(2), 179-201.

Cooper, C. (2005). Tourism: Principles and Practice. London: Prentice Hall.

Fainstein, S. S., \& Judd, D. R. (1999). Cities as Places to Play. Dennis R. Judd \& Susan S. Fainstein (Eds.), The Tourist City içinde (s. 261-273). New Haven: Yale University Press.

Farias, I. (2008). Touring Berlin: Virtual Destination, Tourist Communication and Multiple City. (Yayımlanmamış doktora tezi). Humboldt University, Berlin.

Feifer, M. (1985). Going Places: The Ways of the Tourist from Imperial Rome to the Present Day. London: Macmillan.

Goffman, E. (1959). The Presentation of Self in Everyday Life. New York: Doubleday.

Gottlieb, A. (1982). Americans' Vacations. Annals of Tourism Research, 9, 165-87.

Gray, H. P. (1970). International Travel, International Trade. Lexington: Heath Lexington Books.

Handler, R., \& Saxton, W. (1988). Dissimulation: Reflexivity, Narrative, and the Quest for Authenticity in Living History. Cultural Anthropology, 3, 242-260.

Hewison, R. (1987). The Heritage Industry. London: Methuen.

Huetz De Lemps, C. (1964). Le Tourisme Dans l'Archipel Des Hawaii. Cahiers d'Outre Mer, 17(65), 9-57.

ICOMOS. (1964). International Charter for the Conservation and Restoration of Monuments and Sites: The Venice Charter. Paris: ICOMOS.

ICOMOS. (1987). Charter on the Conservation of Historic Towns and Urban Areas: The Washington Charter. Paris: ICOMOS.

ICOMOS. (1994). The Nara Document on Authenticity. Paris: ICOMOS.

ICOMOS. (1996). The Declaration of San Antonio. Paris: ICOMOS.

ICOMOS. (2014). Nara +20: On Heritage Practices, Cultural Value, and the Concept of Authenticity. Florence: ICOMOS.

Ivanovic, M. (2008). Cultural Tourism. Cape Town: Juta.

Judd, D. R. (1999). Constructing the Tourist Bubble. Dennis. R. Judd, \& Susan S. Fainstein (Eds.), The Tourist City içinde, (s. 35-54). New Haven: Yale University Press.

Kirschenblatt-Gimblett, B. (1998). Destination Culture: Tourism, Museums and Heritage. Berkeley: University of California Press.

MacCannell, D. (1973). Staged Authenticity: Arrangements of Social Space in Tourist Settings. American Journal of Sociology, 79(3), 589-603.

MacCannell, D. (1976). The Tourist: A New Theory of the Leisure Class. New York: Schocken.

Paul, B. D. (2012). The Impacts of Tourism on Society. Annals of Faculty of Economics, 1(1), 500-506.

Richards, G. (2001). Cultural Attractions and European Tourism. New York: CABI Publishing.

UNESCO. (1977). Operational Guidelines for the Implementation of the World Cultural and Natural Heritage. Paris: World Heritage Center.

UNESCO. (2005). Operational Guidelines for the Implementation of the World Heritage Convention. Paris: World Heritage Center. 
UNESCO. (2012). Operational Guidelines for the Implementation of the World Heritage Convention. Paris: World Heritage Center.

Uriely, N. (1997). Theories of Modern and Postmodern Tourism. Annals of Tourism Research, 24(4), 982-984.

Urry, J. (1990). The Tourist Gaze: Leisure and Travel in Contemporary Societies. London: Sage Publication.

Urry, J. (1995). Consuming Places. London: Routledge.

Smith, V. L. (1977). Hosts and Guests: the Anthropology of Tourism. Philadelphia: University of Philadelphia Press.

Smith, D. V. (2002). Tourism and the Formation of the Writer: Three Case Studies. (Yayımlanmamış doktora tezi). Durham University, Durham, England.

Smith, M. K. (2003). Issues in Cultural Tourism Studies. London: Routledge. Walsh, K. (1992). The Representation of the Past: Museums and Heritage in the Post-modern World. London: Routledge.

Wang, N. (1999). Rethinking Authenticity in Tourism Experience. Annals of Tourism Research, 26(2), 349-370. 